\title{
余裕のある日常生活を営むために必要な 高齢女性の身体機能水準
}

\author{
重松 良祐 ${ }^{1)}$ 金 憲 経 ${ }^{2) *}$ 田中喜代次 ${ }^{2)}$ \\ Functional fitness sufficient for achievement of activities \\ parallel to daily living in older community-dwelling women
}

Ryosuke Shigematsu ${ }^{1}$, Hunkyung $\mathrm{Kim}^{2 *}$ and Kiyoji Tanaka ${ }^{2}$

\begin{abstract}
Maintenance of functional fitness is important for activities parallel to daily living (APDL) in older adults. The purpose of this study was to establish the functional fitness level sufficient for the achievement of APDL. For this purpose, the screening power of different thresholds of functional fitness score (FFS) was assessed using the receiver operating characteristics (ROC) curve. One hundred and ninety-two older community-dwelling women served as subjects $(73.0 \pm 7.2 \mathrm{yr})$. FFS was calculated using four functional fitness items (arm curl, walking around two cones, moving beans with chopsticks, functional reach), and the level of achievement of APDL was evaluated by a questionnaire consisting of 16 questions. The sensitivity and false positivity rate of FFS as a screening threshold were analyzed within a cutoff range of -1.250 to 0.250 , and the corresponding ROC curve was plotted to determine the threshold. The sensitivity ranged between $34.6 \%$ and $86.5 \%$. The threshold showing the best equilibrium between sensitivity and specificity approached -0.375 , where the sensitivity and false positivity rate were $63.6 \%$ and $38.7 \%$, respectively. When data from another questionnaire survey were analyzed to determine the criterion-related validity, a sensitivity of $61.9 \%$ and a false positivity rate of $32.2 \%$ were obtained. These results indicate that this threshold could provide useful information for the achievement of APDL.
\end{abstract}

Key words: older adult, functional fitness

(Japan J. Phys. Educ. 44: 334-344, July, 1999)

キーワード：高齢者，身体機能

1. 目的

近年，社会の高齢化がさまざまに論議されてい るなかで, 体育学, 特に運動老年学 (exercise gerontology）の分野は，寝たきり状態に代表さ れる極度に自立度の低い高齢者よりは，むしろ
Katz et al. (1983) のいう活動的余命 (active life expectancy）を伸ばすことのできる比較的自立 度の高い高龄者を対象とした，身体的な自立度を 保持する方策の提示を担っていると思われる。こ れは, 人々の志向が生命の量 (quantity of life) だけでなく生命の質（quality of life）をも重視す るようになってきていること，WHO (1984) が
1）筑波大学大学院体育科学研究科 干305-8574 茨城県つくば市天王台 1-1-1

2) 筑波大学体育科学系 T305-8574 茨城県つくば市天王台 1-1-1

* 先端学際領域研究センター人間生態システ ム研究アスペクト

干305-8574 茨城県つくば市天王台 1-1-1
1. Doctoral Program of Health and Sport Sciences, University of Tsukuba, 1-1-1 Tennodai, Tsukuba, Ibaraki 305-8574

2. Institute of Health and Sport Sciences, University of Tsukuba, 1-1-1 Tennodai, Tsukuba, Ibaraki 305-8574

* Human Beings in the Ecosystem, Center for Tsukuba Advanced Research Alliance, University of Tsukuba, 1-1-1 Tennodai, Tsukuba, Ibaraki 305-8574 
従来までの医学的指標だけでなく身体的な自立度 を高齢者の健康度指標に加えることを勧告してい る，などの動きにも沿っている.

これまでに，四肢や体幹を動かすパフォーマン ステストに基づく高㱓者の身体機能の測定方法が いくつか考案されている（出村ら，1996; Guralnik et al., 1994; Kim and Tanaka, 1995 ; 木村ら, 1989 ; 種田ら, 1994; Osness, 1989; Reuben and Siu, 1990 ; 重松ら，1999). 同時にその評価尺度 も作成されており，データの信頼区間の提示 (Osness, 1989)，パーセンタイル值を用いて順位 を示す方法 (Guralnik et al., 1994 ; 木村ら, 1989; Reuben and Siu, 1990)，測定結果もしくは 因子得点加ら 5 段階に振り分ける方法（出村ら, 1996 ; 種田ら，1996），主成分得点を用いた年齢 尺度 (Kim and Tanaka, 1995; 重松ら，1998） などがある。これらの評価尺度は，対象者が自分 自身の自立度を客観的に把握することができると いう特長を有している。

しかしながら，その自立度がどの程度であれば よいのか，という水準設定はなされていない。収 縮期血圧は140 mmHg 以上（JNC, 1988）, 総コ レステロールが $220 \mathrm{mg} / \mathrm{d} l$ 以上（日本動脈硬化学 会高脂血症診療ガイドライン検討委員会, 1997) であれば治療の対象となるといった水準が見当た らない，身体的自立度は高血圧症や高脂血症と同 様，特定の因子のみによって規定されるとは限ら ないものの，客観的な指標でもってその水準を示 すことが必要である。これまで行なわれてきた高 齢者の身体的な自立度の測定では，標本母体に対 して段階的に振り分けられた標準化による評価や 年齢尺度による評価，つまり相対的な評価が用い られていたが，これからは自立度を保つことので きる水準を絶対値で表すことが求められてこよ う. 具体的な数值目標を設定することは，高㱓者 のライフスタイルの改善を図る際の目安になると 思わ机、そこで本研究では，運動を主体とした 高齢者の健康処方を行なう上で目標となる，自立 した日常生活を営んでいるとみなされる高齢者の 身体機能水準の設定を目的とした。
2. 方法

本研究の目的である身体機能水準の設定につい ては，1992年のアメリカの臨床化学検查標準化 委員会 (National Committee for Clinical Laboratory Standard）の基準值設定の指針に沿った䑪 渡と矢吹（1995）の手順に従った．この手順の 中で本研究に関連する主なものは，(1)測定方法の 決定と水準範囲に影響を及ぼす因子の把握，(2)選 定基準に従った対象者の選定と除外，(3)データの 精製，(4)水準の設定，(5)水準の妥当性の検討，で おる。

以下に，これらの手順に沿って方法を示してい $<$.

\section{（1）測定方法の決定と水準範囲に影響を及ぼす因 子の把握}

パフォーマンステストに基づく高齢者の身体機 能の測定には, 連続上腕屈伸, 8 の字歩行, 豆運 び，ファンクショナルリーチの 4 項目からなる テストバッテリ（重松ら，1999）を用いた。こ のテストバッテリは，入浴・更衣・移乗などの ADL (activities of daily living)よりも高度な身体 能力, つまり外歩きや就業などの社会的諸動作 (生活関連動作, activities parallel to daily living, APDL) に必要な身体能力（松村，1996），を評 価することができる。また 4 項目は，高齢者の 手段的自立や機能的自立に相当する 17 のパフォ ーマンステストを代表する，つまりこの 4 項目 がその17項目の第一主成分を表すとともに（第 一主成分の因子負荷量が0.57-0.85），再検査法に よる信頼性の高いことと（連続上腕屈伸で $\mathrm{r}=$ $0.89,8$ の字歩行で $\mathrm{r}=0.81$, 豆運びで $\mathrm{r}=0.84$, ファンクショナルリーチで $\mathrm{r}=0.93$ ，いずれも有 意)，測定値の分布に偏りのないことを認めてい る(重松ら，1999）。この17項目は文献研究や高 齢者の生活の観察結果に関連していると同時に, APDLの理論的構成を仮定した構成概念妥当性 に基づいていると判断したことから，高蹂者の身 体的な自立度を客観的に表すことができるものと 位置づけた．測定方法は以下の通りである（重松 
ら, 1999).

連続上腕屈伸：背もたれのない椅子に座り，重さ

$2.0 \mathrm{~kg}$ のダンベルを利き手に持たせる。両腕 を自然に下げた状態から，30秒間利き腕の肘 関節を可能な限り早く屈曲・伸展させる（ダン ベルを上下させる)

8 の字歩行 : 床に引かれた $1.5 \times 3.6 \mathrm{~m}$ の長方形の 1 つの長辺の両端にコーンを 1 つずつ置き，正 対する長辺の中央に背もたれのついた椅子を背 中向きに置く．対象者は椅子に座り，合図によ って立ち上がり，右後方にあるコーンを歩いて 回ってから，元の位置まで戻って椅子に座る。

続けて再び椅子から立ち上がり，左後方にある コーンを回ってから，元の位置まで戻って椅子 に座る。これをさらに左右 1 回ずつ繰り返し， 総所要時間を計る.

豆運び：大豆 60 個（直径約 $0.6 \mathrm{~cm}$ ）を入れた容

器 1 （直径 $20.0 \mathrm{~cm}$, 深さ $2.0 \mathrm{~cm}$ ) を左側に, 容器 2（各々 $5.0,3.5 \mathrm{~cm}$ ) を右側に, 両容器の 最短距離を $20 \mathrm{~cm}$ にして並べる．対象者は両容 器に正対するように座り，利き手で持った割り ばしを使って豆を一個ずつ容器 1 から容器 2 へ移す (30秒間).

ファンクショナルリーチ：任意の腕を壁側に近づ けた状熊で壁に横向きに立ち，伸展させた両腕 を肩の高さまで前方に挙げ，その時の第 3 指 の先端を $0 \mathrm{~cm}$ とする.腕を肩と同じ高さに保 ったまま，可能な限り上体を前傾し，両腕の指 先が前方に移動した距離を計測する。このと き，踵は浮かせないようにする。

APDL に焦点をあてて評価を行なっている理 由は，高齢者の大部分がある程度自立しているこ と（古谷野ら，1993；Spirduso, 1995)，さらに APDL を遂行する能力が ADL を遂行する能力よ りも優先的に失われていくと考えられることから （藤田と籏野，1989），APDLの遂行に必要な身 体の能力，つまり身体機能を評価する有用性があ るとの判断に基づいている. 本研究ではこの身体 機能の水準を，標準化した 4 項目の総合スコア (functional fitness score: FFS) で表すこととす る.その算出式は以下の通りである（重松ら，
1998)

$$
\mathrm{FFS}=0.072 \mathrm{X}_{1}-0.075 \mathrm{X}_{2}+0.090 \mathrm{X}_{3}
$$$$
+0.041 \mathrm{X}_{4}-2.11
$$

ただし， $\mathrm{X}_{1}$ : 連続上腕屈伸 (回 $/ 30$ 秒), $\mathrm{X}_{2}$ : 8 の字歩行 (秒), $\mathrm{X}_{3}$ : 豆運び (個 $/ 30$ 秒), $\mathrm{X}_{4}$ : ファンクショナルリーチ $(\mathrm{cm})$ である。なお， この FFS は先に紹介した17項目の第一主成分得 点との間に高い相関係数が示され（Pearsonの積 率相関係数で $0.88, P<0.05)$ ，また 17 項目の第一 主成分得点を従属変数に，4項目の測定結果を独 立変数とした重回帰分析では $\mathrm{R}=0.91$ と有意な重 相関係数が示された (未発表資料)。これらのこ とから，4つのパフォーマンステストで身体機能 をとらえることができるものと思われる．

日常生活における自立度の評価は，自己申告に よる金ら（1994）の質問紙に準じた。この質問 紙は，高齢者が日常生活において成就困難と感じ られる動作抢よび日常生活に必要とされる諸動作 を参考にして作成されている４つの下位尺度 （全身の移動，上肢の操作，手指の操作，起立 · 姿勢変換：各 4 問ずつ）の 16 問からなっている （付録 1). 説明後，対象者各自による回答を求め たが，視力が低下しているために独力での回答が 困難と判断できた対象者には対面式にて調査を行 なった。これらの質問は，身体機能測定の実施と 同日に行なった．各設問のスコアを，「できない」 1 点,「あまりできない」 2 点,「どちらでもない」 3 点「ある程度できる」4 点，「十分にできる」 5 点として，16問の総合得点を算出した（16-80 点).

さらに，古谷野ら（1987）の東京都老人総合 研究所（都老研）の活動能力指標（付録 2) を, 設定した水準の妥当性の検討に用いた．この指標 は地域で独立した生活を棠むうえで必要とされる 活動能力を測定するための尺度であり，手段的自 立, 知的能動性, 社会的役割の 3 つの下位尺度 で構成されている。これらの下位尺度は Lawton （1972）の活動能力指標の体系にある理論的仮説 に一致している（古谷野ら，1987）。「はい」を 1 点，「いいえ」を 0 点とし，13問の総合得点を 算出した（0-13点：妥当性の検討方法について 
は，(5)の身体機能水準の妥当性の検討を参照).

また，身体機能に影響を及ぼす因子として性や 年齢などが挙げられるものの（出村ら，1996； 木村ら，1989; 野間, 1993), 本研究では女性の みを用いていること，どのような年龄にあっても APDLの遂行は必要であること,さらには先に 示したように各テスト項目の再現性が高かった （重松ら，1999）ことから，水準に影響を及ぼす 因子は特に設定しなかった。

\section{（2）対象者の選定亡除外基準}

対象者は茨城県に在住している60歳以上の女

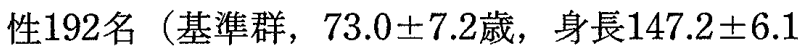
$\mathrm{cm}$ ，体重 $50.2 \pm 7.2 \mathrm{~kg}$ ）とした。長年にわたり 高齢者之有疾病者の運動処方に携わっている研究 者らが，対象者の身体活動量と所属している団体 の活動内容を予聴き取り調査することで，身体 機能や日常生活における自立度の個人差（散らば り度）を大きくすることに努めた（対象者はすべ て何らかの団体に所属していた)。身体活動量の 聴き取りには，総務庁統計局の社会生活基本調查 報告に記載されている生活時間の分類を用いた。 生活時間は一次活動（睡眠や食事などの生理的活 動), 二次活動（家事や仕事などの義務的活動）, 三次活動(テレビ鑑賞やスポーツなどの余暇活動) に分類されている. 本研究では，二次活動をほと んぞ行なっていないと判断された対象者（19名） や三次活動（特にスポーツ）を多く行なっている と判断された対象者（19名）も含めた。 また， 所属している団体の活動内容の判断をもとに，ク ロッケーの練習を週に 2-3 回行なっている対象 者（2団体18名), 詩吟やカラオケなどを月に 12 回実施している対象者 (3 団体33名) も含めた.

なお，日常生活に支障を来していない，つまり 介助を必要としていないこと（厚生省の寝たきり 度判定基準ランク $\mathrm{A}$ 以上), 約 3 力月以内に入院 のために臥休中心の生活を送っていなかったこと を本人もしくは家族・知人への問診によって確認 した.

\section{（3）データの処理}

結果は平均值士標準偏差で表した. 測定項目に おける暦年齢を因子とした平均值の差異は，一元 配置の分散分析によって検討した． $F$ 值が有意で あると確認された場合, Scheffe の post hoc test を施し，どの年代間に差異があるかを確認した。 有意水準は $5 \%$ とした. FFS の信頼性は，再検 査法によるPearsonの積率相関係数（r）で評価 した。また，池田（1973）の重み付き合成得点 に抢ける信頼性係数 $(\rho)$ も併せて算出した。こ の信頼性係数は, 測定値の分散中に占める真值の 分散の割合を表したものである。算出方法は，(1) 主成分得点を算出する際の係数の 2 乗，(2)測定 值の分散值，(3)信頼性係数を 1 から引いたもの, の積を各項目ごとに求め，その総和を FFS の分 散で除し，さらに 1 から引いたものである.

各測定項目々暦年齢の分布図から久て著しく飛 び離れていたデータには，交差検定を施した．交 差検定は，説明の困難なデータが含まれている場 合に，同一個人から得られた他項目のデータをも とに棄却か否かを総合的に判断する検定法である （出村，1996）。ただし，高齢期には障害や疼痛 などのために特定の項目の值が低くなることも考 えられるので, 確認もしくは再測定が困難な場合 は充却したが，研究者らがその対象者の結果を合 理的であると判断した場合には棄却しなかった。

\section{（4）身体機能水準の設定}

身体機能水準の設定にはさまざまな方法（Bohannon, 1997; Cureton and Warren, 1990; Posner，1995）がとられているが，本研究では receiver operating characteristic (ROC) 曲線（市 原，1995; Swets，1998）を用いて水準を設定し た.この方法は, 表 2 に示すように水準を変化 させた際, 感度と偽陽性率がどのように変化する かを連続的に検討するものである（市原， 1995). 本研究で用いている感度とは, 自立して いない対象者を自立していないと正しく判定する 確率を指し，偽陽性率とは自立している対象者を 自立していないと誤って判定する確率のことであ る. 
以下に，本研究で行なった身体機能水準の設定 手順を示す，日常生活を余裕をむって遂行してい くためには, 種々の動作を「ある程度できる」こ とが必要であると判断し，金ら（1994）の自立 度スコアが平均 3.5 点以上（総合得点で56点以上） 示す対象者を「余裕をもって遂行している群（自 立群：以下，A群）」と定義し，それ以外の対象 者をB 群として全体を 2 つに分けた．ただし， 総合得点で56点を示した対象者のなかで， 1 問で も 1 点（できない）に○を付けた場合は自立し ていないとみなした。 また，任意の下位尺度（例 えば「全身の操作」：付録 1 を参照）の設問 4 問 すべてが 2 点（あまりできない）であった場合 も，類似した動作に抢ける自立度が極端に低いと いう判断から，本研究で定義する自立に達してい ないとみなし，B 群に移して分析した。

ROC 解析において暫定的に設定する水準は 5 つ以上が望ましいとされていること（Swets， 1998), Bortheiry et al. (1994) は水準を10個設定 していること, 対象者全員のFFS の平均值が -0.43であったことなどから，FFSを0.25-1.25 まで 0.125 間隔で計 13 個を暫定的に設定し (任意に設定した身体機能水準)，それぞれに打け る感度および偽陽性率を算出した．感度とは「任 意に設定した身体機能水準を下回っている B 群 の対象者数/B 群全体の対象者数」を指し，偽陽 性率とは「任意に設定した身体機能水準を下回っ ている $\mathrm{A}$ 群の対象者数/A 群全体の対象者数」を 指す。ここで，任意に設定した身体機能水準を下 回るということは，APDLに含まれる種々の動 作が「ある程度できる」には満たない（十分には できない）ことを意味している.

次に, 感度抢上び偽陽性率が 2 次曲線上に散 布しているとの仮定（市原，1995）にならい， 曲線回帰分析を施した．そして，その曲線上で感 度が最も高く，偽陽性率が最も低くなる点を求 め，それに相当する 1 つ身体機能水準を最終 的に決定した。

\section{（5）身体機能水準の妥当性の検討}

設定した身体機能の水準の妥当性を，古谷野ら
（1987）の活動能力指標から検討した．この古谷 野ら（1987）の質問紙は，地域での独立した生 活を営むうえで必要とされる活動能力の評価を仮 定していることから，金ら（1994）の自立して 豊かな日常生活を営むのに必要な能力を評価する としている質問紙と，手段的自立や機能的自立と いう観点からみて同等であると位置づけた。 た，古谷野ら（1987）の質問紙では各質問が「は い」，「いいえ」の 2 件法で尋るられていること から，13点満点を「日常生活の動作をある程度 できる」と定義した．対象者全体を 13 点満点の 対象者と，それ未満の点数の対象者とに分け，(4) で設定した身体機能水準を適用した場合の感度と 偽陽性率を算出した（異なる指標による水準の妥 当性, criterion-related validity).

\section{3. 結 果}

表 1 に年路，対象者数，暦年齢，FFS 抢よび それを構成する 4 項目, 自立度スコア, 都老研 の活動能力指標の結果を，5歳ごとの区分と全体 の観点から示した。いずれの項目にも年代間に有 意差が認められ，加齢にともなって種々のスコア の低下していくことが認められた. FFS の信頼 性（池田，1973）では， $\rho=0.92(P<0.05 ）$ と 有意な係数が得られた。 また，23名（74.8 06.5 歳）に対して実施した FFS の再検查の結果から 得られた Pearson の積率相関係数は $\mathrm{r}=0.95(P$ <0.05）であった．金ら（1994）の質問紙の信 頼性は同じ23名に対する再検査の結果より, $\mathrm{r}=$ $0.96(P<0.05)$ と算出された.

表 2 に FFS を任意に変動させた際の感度と偽 陽性率の変化を示した．FFSを0.250に設定した 場合，感度は $86.5 \%$ と高いものの，偽陽性率は $65.7 \%$ と算出された，以下，FFS を0.125ずつ -1.250末で低下させた．FFSをー1.250に設定 した場合, 感度は $34.6 \%$ と低いものの, 偽陽性率 は12.9\%まで低下した。これら13個設定した水準 に抢ける感度と偽陽性率を散布四に表したとこ ろ，図1のようになった。これらの点が 2 次曲 線上にあるという判断（市原，1995）で回帰し たところ， 
Table 1 Age, number of subjects, functional fitness score (FFS), and each variables, index of ability of daily living activity (Kim index), index of competence in the elderly living at home (Koyano index) in each 5 years category

\begin{tabular}{|c|c|c|c|c|c|c|c|c|c|}
\hline & Total & $60-64$ & $65-69$ & $70-74$ & $75-79$ & $80-84$ & $85+$ & $F$ value & Post hoc test th \\
\hline Number & 192 & 26 & 36 & 50 & 45 & 24 & 11 & & \\
\hline Age & $73.0(7.2)$ & $62.2(1.3)$ & $66.6(1.2)$ & $72.1(1.2)$ & $76.9(1.5)$ & $82.2(1.3)$ & $87.0(2.9)$ & $935^{*}$ & $60<65<70<75<80<85$ \\
\hline FFS & $-0.43(0.91)$ & $0.56(0.81)$ & $-0.08(0.60)$ & $-0.21(0.54)$ & $-0.78(0.72)$ & $-1.31(0.79)$ & $-1.63(0.88)$ & $30.9^{*}$ & $\begin{array}{l}60>65,70,75,80,85 \\
65,70>75,80,85\end{array}$ \\
\hline Arm curl (n/30 s) & $20.8(5.1)$ & $24.2(5.9)$ & $21.4(4.3)$ & $22.3(4.4)$ & $19.5(4.7)$ & $17.6(4.1)$ & $17.3(5.2)$ & $8.1^{*}$ & $\begin{array}{l}60>75,80,85 \\
70>80\end{array}$ \\
\hline Walking ${ }^{\# 1}(\mathrm{~s})$ & $25.7(6.0)$ & $21.2(3.7)$ & $21.9(4.0)$ & $24.6(4.2)$ & $27.2(4.2)$ & $32.5(6.5)$ & $32.5(7.4)$ & $25.7^{*}$ & $\begin{array}{l}60,65<75,80,85 \\
70<80,85 ; 75<80\end{array}$ \\
\hline Moving beans ( $\mathrm{n} / 30 \mathrm{~s}$ ) & $11.8(3.3)$ & $14.7(4.2)$ & $12.1(2.8)$ & $11.6(2.4)$ & $11.2(3.0)$ & $10.5(3.7)$ & $9.9(2.6)$ & $6.6^{*}$ & $60>70,75,80,85$ \\
\hline Functional reach $(\mathrm{cm})$ & $27.7(8.0)$ & $33.6(7.6)$ & $29.5(7.2)$ & $29.9(6.3)$ & $24.9(7.6)$ & $23.5(6.3)$ & $17.9(7.4)$ & $12.4^{*}$ & $\begin{array}{l}60,70>75,80,85 \\
65>85\end{array}$ \\
\hline Kim index ${ }^{t^{2}}$ & $63.8(12.7)$ & $72.6(11.4)$ & $70.2(9.3)$ & 64.4(11.4) & $59.9(11.9)$ & $57.3(12.5)$ & $49.8(10.1)$ & $11.6^{*}$ & $\begin{array}{l}60,65>75,80,85 \\
70>85\end{array}$ \\
\hline Koyano index ${ }^{f 3}$ & $11.6(1.8)$ & $12.4(1.2)$ & $11.8(1.9)$ & $11.8(1.2)$ & $11.5(2.0)$ & $11.4(1.8)$ & $9.6(3.0)$ & $4.3^{*}$ & $60,65,70>85$ \\
\hline
\end{tabular}

The numbers in the parentheses indicate the standard deviations.

${ }^{\# 1}$ Walking around two cones, ${ }^{\# 2}$ Kim et al. (1994), "\#3oyano et al. (1987), ${ }^{44}$ Post hoc test using Scheffe's confidence interval.

${ }^{*} P<0.05$.

Table 2 Characteristics of different cutoff points of functional fitness score (FFS)

\begin{tabular}{|c|c|c|c|c|c|c|}
\hline \multirow{2}{*}{ FFS } & \multicolumn{3}{|c|}{ Sensitivity ${ }^{\# 1}$} & \multicolumn{3}{|c|}{ False positive rate ${ }^{\# 2}$} \\
\hline & $\%$ & above $^{\sharp 3}$ & below ${ }^{\# 4}$ & $\%$ & above ${ }^{\# 3}$ & below $\# 4$ \\
\hline 0.250 & 86.5 & 7 & 45 & 65.7 & 48 & 92 \\
\hline 0.125 & 84.6 & 8 & 44 & 60.0 & 56 & 84 \\
\hline 0.000 & 78.8 & 11 & 41 & 55.7 & 62 & 78 \\
\hline-0.125 & 76.9 & 12 & 40 & 50.0 & 70 & 70 \\
\hline-0.250 & 69.2 & 16 & 36 & 44.3 & 78 & 62 \\
\hline-0.375 & 61.5 & 20 & 32 & 38.6 & 86 & 54 \\
\hline-0.500 & 59.6 & 21 & 31 & 35.7 & 90 & 50 \\
\hline-0.625 & 59.6 & 21 & 31 & 33.6 & 93 & 47 \\
\hline-0.750 & 51.9 & 25 & 27 & 25.7 & 104 & 36 \\
\hline-0.875 & 40.4 & 31 & 21 & 22.1 & 109 & 31 \\
\hline-1.000 & 38.5 & 32 & 20 & 17.1 & 116 & 24 \\
\hline-1.125 & 34.6 & 34 & 18 & 16.4 & 117 & 23 \\
\hline-1.250 & 34.6 & 34 & 18 & 12.9 & 122 & 18 \\
\hline \multicolumn{7}{|c|}{$\begin{array}{l}\text { \#1 Sensitivity was calculated using the number of } \\
\text { the subjects showed more than } 56 \text { points in } \\
\text { Kim's index. }\end{array}$} \\
\hline \multicolumn{7}{|c|}{$\begin{array}{l}\text { \#2 False positive rate was calculated using the num- } \\
\text { ber of the subjects showed less than } 56 \text { points in } \\
\text { Kim's index. }\end{array}$} \\
\hline
\end{tabular}

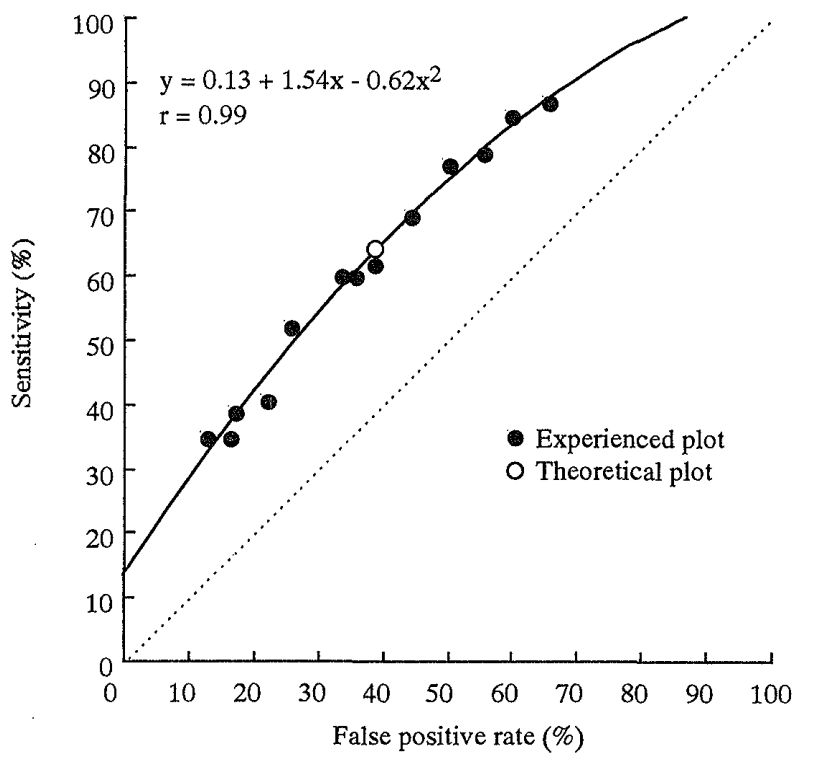

Fig. 1 Receiver operating characteristics (ROC) curve for functional fitness score. The 45 degree dashed line through the origin indicates the ROC curve of a test exhibiting discriminatory ability not better than chance. 
$\mathrm{y}=0.13+1.54 \mathrm{x}-0.62 \mathrm{x}^{2}$

( $\mathrm{x}$ : 偽陽性率, $\mathrm{y}:$ 感度 $)$ が得られた $(r=0.99, P<0.05)$. 次にこの 2 次 曲線上にあり，図 1 に打ける左上隅の点との直 線距離が最小になる点を求めたところ, 白丸 $(\bigcirc)$ で表している座標 $(0.387,0.636)$ となった。つ まり，感度を $63.6 \%$ ，偽陽性率を $38.7 \%$ としたと きに, 左上隅の点 (2 群を完全に判別することの できる点）に最も近くなることが分かった．表 2 より，このような感度と偽陽性率になる最も近 似したFFSはー0.375であった。よって，この 一0.375を，日常生活を余裕をもって遂行するこ とのできる身体機能の水準とした。なお，設定し た水集前後 $(-0.38-0.37)$ のスコアを示す対 象者（6名）は， $72.2 \pm 3.9$ 歳，身長 $147.7 \pm 2.3$ $\mathrm{cm}$, 体重 $51.0 \pm 4.4 \mathrm{~kg}$ であり（基準群の平均值 々の間に有意差なし), 連続上腕屈伸 $21.9 \pm 5.6$ 回 $/ 30$ 秒, 8 の字歩行 $26.2 \pm 3.6$ 秒, 豆運び12.4 \pm 3.0 個 $/ 30$ 秒，ファンクショナルリーチ $25.8 \pm 3.8 \mathrm{~cm}$ であった.

ところで, $\mathrm{FFS}=-0.375$ より $\mathrm{FFS}=$ -0.625の方が有用であるととらえることもでき る（表 2)。それは，感度が $\mathrm{FFS}=-0.375$ の時に 比べて $1.9 \%$ 低下する一方で，偽陽性率が5.0\%も 低下するためである。しかしながら，図 1 上の 左上隅の点は感度が高く，偽陽性率が低いことを 意味すること加ら，左上隅点との直線距離の小さ い点（水準）が望ましいこと，水準を高めに設定 することで高齢者の健康処方に対して教育的（啓 発的）な効果をよりもたらすことなどを勘案し， 最終的に FFS $=-0.375$ を身体機能水準として採 用した。

Criterion-related validity の検討として，古谷 野ら（1987）の活動能力指標において13点満点 であった対象者87名と，13点末満の対象者105名 とに分けて FFS $=-0.375$ 適用した場合の感度 と偽陽性率を求めた。 その結果, 感度 $61.9 \%$ (水 準を下回った者65名，上回った者40名：計算式 は方法(4)を参照)，偽陽性率が32.2\%（同28名， 59名）となり，感度では金ら（1994）の自立度 スコアで検討した際と同様の検出力が認められ，
偽陽性率では低下することが認められた。

\section{4. 考察}

これまでに，相対評価ではなく絶対評価からみ た水準設定は，いくつか報告されている，ROC 解析を用いていない研究において, Bohannon （1997）は握力にみられる筋力が個人の筋力の低 下の程度を表わす指標であること，および筋力の 低下が身体機能の低下と関連があることを前提と して，20-79歳までの対象者（男性106名, 女性 125名）のデータをもとにした握力の水準設定を 検討している．この水準は対象者の性，暦年齢， 体重を説明変数とした重回帰式によって求められ るようにしている. Cureton and Warren (1990) は，5-17歳の子どもの良好な健康状態の保持に 必要な体力水準を設定する立場から，絶対評価の 必要性を述べている，最大酸素拱取量が成人にお ける健康状態や疾病の危険因子に大きく関連して いることを前提に, 男子では $42 \mathrm{ml} / \mathrm{kg} / \mathrm{min}$ (517歳), 女子では $40 \mathrm{~m} l / \mathrm{kg} / \mathrm{min}$ (5-9 歳) または 39-35 $\mathrm{ml} / \mathrm{kg} / \mathrm{min} （ 10-17$ 歳）を最低限の水準と している.

ROC 解析を用いた研究においては, 日本骨代 謝学会の骨粗鬆症診断基準検討委員会が, 腰椎 X 線像で骨萎縮度 I 度と II 度を最も効率よく識 別する腰椎密度を決定している，それによると， 若年成人（20-44歳）に招ける平均骨塩量の -2.5 SD を許容範囲としている(折茂ら，1997)， Bortheiry et al. (1994) 女同様に ROC 解析を用 いて, 糖尿病か否かの診断ならびに耐糖能を, 毛 細血管から得られる血糖値で判別しようと試みて いる.

このように水準設定についての報告はいくつか なされてはいるものの，高齢期においては各自測 定值がそれまでの環境（栄養, 教育, 経済状態, 職業など）の影響を大きく受けていると考えられ ることから，性・年齢を統一化した集団を抽出し てもその中でのばらつきが大きく（野間， 1993)，水準設定が困難である. また，健康に関 連する体力は “将来, 健康な人生を送る可能性が 高い”レベルに維持することが大切であり，それ 
以上の体力は必要でないという最低限の水準を提 示するという考えもある（田畑，1997）。このよ うななか，体力の低下が自立度の判定に有用であ ることを仮定とした，高齢者における水準設定が いくつか報告されている（Judge et al., 1996 ; 中 山と道場, 1998; Posner et al., 1995; Shephard, 1987; William and Hornberger, 1984). Posner et al.（1995）は平均69.4歳の女性61名を対象にした 研究に打いて，自立度（ADL）を表す質問紙の 結果を最も精度良く推定する筋力の項目が，ヒラ 又筋 $(\mathrm{R}=0.76, P<0.001)$ 飞腓腹筋 $(\mathrm{R}=0.65$, $P<0.001)$ であることを確認したうえで，それ ぞれの $1 \mathrm{RM}$ が $30 \mathrm{~kg}, 45 \mathrm{~kg}$ になるまで自立度が 改善していくことを示唆している.この研究で は，ヒラメ筋・腓腹筋の測定値と自立度（質問紙 の得点）との散布図から必要な水準が，ROC 解 析ではなく視覚的に設定されている．中山と道場 （1998）は高齢慢性心不全患者の QOL の維持に 必要な体力レベルが， 6 分間歩行において100 m 以上, 身体活動能力指数 (SAS-METs) に扔い て 4 METs 以上と想定している.これは，その 水準以下の成績を呈する患者の睡眠度, 健康感, 社会参加が顕著に低くなっていることに基づいて いる。また，Shephard (1987) は，身体的に自 立するために必要な最大酸素摂取量の值を 13 $\mathrm{m} l / \mathrm{kg} / \mathrm{min}$ であるとしている。

本研究では, 自立した日常生活を営んでいると みなされる60歳以上の女性の身体機能水準を, 標準得点にて規定した. データ処理の結果，日常 生活の種々の動作を余裕を持って遂行していると みなされた者の身体機能は FFS $=-0.375$ 以上で あることが示唆された，ROC 解析を用いた分析

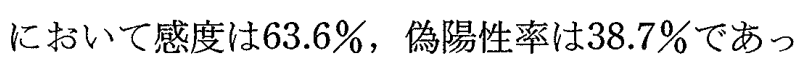
た. Herbert et al. (1996)のまとめたレビューで は，自立度を質問紙で判別している先行研究での 感度と偽陽性率が報告されている。それによると

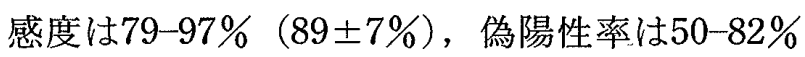
$(67 \pm 12 \%)$ であった。本研究に抢ける結果はこ れらに比べて偽陽性率は低く良好であったもの の, 感度は低かった。 感度が低い理由として, 本 研究で対象とした高齢者の身体機能が全体的に高
かったと同時に，日常生活にお打る諸動作を「ど ちらでもない」もしくは「ある程度できる」とい う高い水準で自立度を定義したためと思われる。 しかしながら，質問紙の結果からではなく，高齢 前期 (74歳未満 : 112名) と高齢後期 (75歳以上： 80名）というように暦年齢で分けてから同様の ROC 解析を行なったところ，高齢前期では感度 が31.3\%（水準を下回った者 5 名，上回った者 11名：計算式は方法(4)参照），偽陽性率が $26.0 \%$ (同71名，25名），高齢後期では感度が75.7\%（同 28名，9名），偽陽性率が51.2\%（同21名，22名） となった。高齢後期での偽陽性率は高齢前期の 2 倍近くにもなったものの, 感度はそれ以上に増 加した.このことから, 設定した水準は健康処方 に怙けるスクリーニングとしての役割を果たす可 能性が後期高齢者において大きくなると示唆され た。また，本研究では金ら（1994）の質問紙の 総合得点（自立度スコア）において 56 点以上と 56 点未満に分けて分析を行なっている。これと は別に，対象者全体を $24,40,56,72$ 点を境に分割 して同様の ROC 解析を行なった（つまり 1 質問 あたり $1.5,2.5,3.5,4.5$ 点に相当し，全体を 5 分 割して解析を行なった). 40点未満を示す対象者 数が少なかったため, 56 点未満の群に統合し $(\mathrm{n}=52) ， 72$ 点以上を示した群 $(\mathrm{n}=70)$ の両群 の結果に ROC 解析を施した. その結果, FFS = -0.380の時に最も精度よく 2 群を識別すること ができた．次に56-72点を示した対象者（69名） に設定した水準を適用すると，水準を上回った対 象者は31名, 下回った対象者は38名と69名がほ ぼ2分された結果が示された。これらのこと， および先に検討した criterion-related validity $の$ 結果から，設定した身体機能水準の妥当性が示唆 された。

日常生活における種々の動作能力の低下は社会 的な背景 (取入状況など) や健康状況に左右され， 加齢による影響力よりも大きい (Seeman et al., 1994）とされることから，身体機能（FFS）の みで規定することには限界があろう。市た，本研 究で行なったように 2 群を識別するためには口 ジスティックモデルや判別関数を用いることも可 
能であるが，本研究では単に 2 群を精度よく識 別するだけでなく，任意に水準を設定することが 可能であること（Zweig and Campbell, 1993）も 必要と考えたため，ROC 解析を用いた．高龄者 自身に自立度低下を抑えるためのライフスタイル の改善を早い段階で求める必要性の高いことを考 慮すると, FFS $=-0.375$ よりも高い水準で目標 を設定することもできよう。

以上，設定した身体機能水準は本研究で用いた 高齢女性を対象に，主観的な情報（質問紙）の結 果を基盤としていることから，データ量および解 析精度に限界がある。本研究ではそのような限界 を踏をえながら，日常生活における種々の動作を 独力で余裕をもって遂行するために必要な身体機 能水準に関するアイディアおよびその水準を提案 した。この水準を用いて，対象者の身体機能を拠 り所に適切な健康処方を行なうことができると思 われる，今後は，今回用いた対象者とは異なる高 齢者に身体機能水準を適用するとともに（交差妥 当性の検討)，水準以下の対象者の身体機能の保 持（もしくは向上）を試みる運動プログラムの開 発およびその効果の検証が求められてこよう。

\section{5. ま と め}

本研究では，日常生活の種々の動作を独力で余 裕をもって遂行しているとみなされる高粭者の身 体機能水準を絶対值で表すことを目的とした。 192名の高齢女性（73.0土7.2歳）を対象に，質問 紙から得られる日常生活の自立度の評価結果をも とに，連続上腕屈伸， 8 の字歩行，豆運び，ブァ ンクショナルリーチの 4 項目から算出される標 準得点（FFS）で設定した. ROC 解析の結果， $\mathrm{FFS}=-0.375$ 以上の身体機能が必要であること が示唆された．対象者の数や，設定した水準の基 盤となる質問紙の結果が主観によるものであるこ と，などの限界はあるものの，本研究で設定した 絶対值の水準は運動を主体とした高齢者の健康処 方に用いることができると思われる．

\section{謝辞}

本研究は, 筑波大学先端学際領域研究センター
人間生態システム研究アスペクト（田中プロジェ クト）の支援によって行なわれた。

\section{文献}

Bohannon, R. W. (1997) Reference values for extremity muscle strength obtained by hand-held dynamometry from adults aged 20 to 79 years. Arch. Phys. Med. Rehabil. 78: 26-32.

Bortheiry, A. L., Malerbi, D. A., and Franco, L. L. (1994) The ROC curve in the evaluation of fasting capillary blood glucose as a screening test for diabetes and IGT. Diabetes Care 17: 1269-1272.

Cureton, K. L. and Warren, G. L. (1990) Criterionreferenced standards for youth health-related fitness tests: A tutorial. Res. Q. 61: 7-19.

出村慎一 (1996) 健康・スポーツ科学のための統計学. 大修館書店 : 東京, pp. 321-323.

出村慎一 · 中比呂志 ·春日晃章 ·松沢甚三郎 (1996) 女性高龄者に抢汀万体力因子構造と基礎体力評価の ための組テストの作成. 体育研 41: 115-127.

藤田利治・籏野脩一（1989）地域老人の日常生活動作 の障害とその関連要因. 日公衛誌 36: 76-87.

船渡忠男 - 矢吹重光 (1995) 年龄 - 性 - 人種差を考慮 した正常値（基準値・基準範囲）の設定. 日臨 53(増 刊) : 29-34.

Guralnik, J. M., Simonsick, E. M., Ferrucci, L., Glynn, R. J., Berkman, L. F., Blazer, D. G., Scherr, P. A., and Wallace, R. B. (1994) A short physical performance battery assessing lower extremity function: Association with self-reported disability and prediction of mortality and nursing home admission. J. Gerontol. 49: M85-M94.

Hebert, R., Bravo, G., Korner-Bitensky, N., and Voyer, L. (1996) Predictive validity of a postal questionnaire for screening community-dwelling elderly individuals at risk of functional decline. Age Ageing 25: 159-167. 市原清志（1995）正常值（基準值 - 基準範囲）・異常值 に対する考え方。日臨 53(増刊)：9-28.

池田 央 (1973) 心理学研究法 8: テストII. 東京大 学出版会 : 東京, pp. 87-91.

Joint National Committee on Detection, Evaluation, and Treatment of High Blood Pressure (JNC) (1988) The 1988 report of the Joint National Committee on detection, evaluation, and treatment of high blood pressure (JNC-V). Arch. Intern. Med. 153: 154-183.

Judge, J. O., Schechtman, K., Cress, E., and FICSIT Group (1996) The relationship between physical performance measures and independence in in- 
strumental activities of daily living. J. Am. Geriatr. Soc. 44: 1332-1341.

Katz, S., Branch, L. G., Branson, M. H., Papsidero, J. A., Bech, J. C., and Greer, D. S. (1983) Active life expectancy. N. Engl. J. Med. 309: 1218-1224.

金 禧植・稲垣 敦 - 田中喜代次 (1994) 高齢女性の 日常生活における活動能力を評価するための簡易質 問紙の作成. 体力科学 43: 175-184.

Kim, H. S. and Tanaka, K. (1995) The assessment of functional age using "Activities of daily living" performance tests: A study of Korean women. JAPA 3: $39-53$.

木村みさか・平川和文・奥野 直 - 小田慶喜 - 森本武 利 · 木谷輝夫 - 藤田大祐 - 永田久紀 (1989) 体力診 断バッテリーテストからみた高齢者の体力測定值の 分布括よび年齢との関連. 体力科学 38: 175-185.

衣笠 隆・長崎 浩. 伊東 元・橋詰 謙. 古名丈人 · 丸山仁司 (1994) 男性（18～83歳）を対象にした 運動能力の加龄変化の研究. 体力科学 43: 343-351.

古谷野亘 - 柴田 博 - 中里克治 - 芳賀 博 - 須山靖男

（1987）地域老人に抢ける活動能力の測定. 日公衛誌 34: 109-114.

古谷野亘 - 橋本廸生 - 府川哲夫 - 柴田 博 - 郡司篤晃 （1993）地域老人の生活機能一老研式活動能力指標に よる測定值の分布一. 日公衛誌 40: 468-473.

Lawton, M. P. (1972) Assessing the competence of older people. Kent, D. P. et al. (ed.) Research Planning and Action for the Elderly: The Power and Potential of Social Science. Behavioral Publications: New York, pp. 122-143.

松村 秩 (1996) 生活関連活動. 土屋弘吉, 今田 拓, 大川嗣雄(編). 日常生活活動（動作）一評価と訓練 の実際一. 医歯薬出版 : 東京, pp. 67-82.

中山 豪・道場信孝 (1998) 高龄者心不全患者に括け る QOL と体力評価. 体力科学 47: 17-18.

日本動脈硬化学会高脂血症診療ガイドライン検討委員 会（1997）高脂血症診療ガイドライン. 動脈硬化 25: $1-34$.

野間昭夫（1993）老人の基準範囲. 臨床検査 37: 966970.

種田行男 - 荒尾 孝. 西嶋洋子. 北畠義典 · 永松俊哉 - 一木昭男 ·江橋 博 - 前田 明 (1996) 高㱓者の 身体的活動能力（生活体力）の測定法の開発. 日公 衛誌 43: 196-207.

折茂 肇・杉岡洋一・五来逸雄・中村哲郎・福永仁夫 ·彿淵孝夫・武藤芳照（1997）原発性骨粗磼症の診 断基準. The Bone 10: 19-24.

Osness, W. H. (1989) Assessment of physical function among older adults. David, K. L. (ed.) Mature Stuff. Physical Activity for the Older Adult. American Alliance for Health, Physical Education, Recreation, and Dance: Virginia, pp. 93-118.

Posner, J. D., McCully, K. K., Landsberg, L. A., Sands, L. P., Tycenski, P., Hofmaxx, M. T., Wetterholt, K. L., and Shaw, C. E. (1995) Physical determinants of independence in mature women. Arch. Phys. Med. Rehabil. 76: 373-380.

Reuben, D. B. and Siu, A. L. (1990) An objective measure of physical function of elderly outpatients - The physical performance test-. J. Am. Geriatr. Soc. 38: 1105-1112.

Seeman, T. E., Charpentier, P. A., Berkman, L. F., Tinetti, M. E., Guralnik, J. M., Albert, M., Blazer, D., and Rowe, J. W. (1994) Predicting changes in physical performance in a high-functioning elderly cohort: MacArthur studies of successful aging. J. Gerontol. 49: M97-M108.

Shephard, R. (1987) Adapting physical activity to an aging population. Int. J. Sports Cardiol. 4: 1-13.

重松良祐 - 田中喜代次 ·渡邊 寛・檜山輝男 (1998) 高齡者の日常生活に必要な身体機能の評価尺度。 Geriatric Medicine 36: 927-932.

重松良祐・金憲経・張美蘭・上野リンダ・田中喜代次 （1999）高齢邦人女性の身体機能を評価するテストバ ッテリの作成一低水準から高水準への適用を目指し て一。 日公衛誌 46: 14-24.

Spirduso, W. W. (1995) Physical Dimensions of Aging. Human Kinetics: Illinois, pp. 329-365.

Swets, J. A. (1998) Measuring the accuracy of diagnostic system. Science 240: 1285-1293.

田畑 泉（1997）健康に関連する体力。体育の科学 47: 852-857.

William, M. and Hornberger, J. (1984) A quantitive method of identifying older persons at risk for increasing long-term care services. J. Chon. Dis. 37: 705710.

World Health Organization (1984) The Use of Epidemiology in the Study of the Elderly. WHO: Geneva.

Zweig, M. H. and Campbell, G. (1993) Receiver-operating characteristic (ROC) plots: A fundamental evaluation tool in clinical medicine. Clin. Chem. 39: 561577.

\section{付録 1 日常生活に抢ける自立度の質問紙}

（1）休まずに 4 階まで階段を昇れる

(金 5,1994$)$ 
（2） デコボコ道を倒れないで速く歩ける

（3）急ぎ足で30分ほど歩き続けられる

（4）人や物にぶつかりそうになった時，すばやくよ けられる

（5）布団を干したり，取り込んだりできる

（6）上着やコートにすばやく両腕を通せる

(7) 布団などの上げ下ろしができる

（8）強く締まっている大ビンのねじブタを開けられ る

（9）シャツや洋服のボタンをすばやくはめられる

(10) 包丁で果物の皮をむける

(11) はさみで線にそって紙を切れる

(12) 靴のひもをすげやく結べる

(13) しゃがんだ姿勢から手を使わないで立ち上がれ る

(14) 床に落ちた物を膝を伸ばして拾える

(15) 正座の姿勢で手を伸ばして後ろの物をとれる

(16) ズボンをはいたり始いたりすることが楽にでき る

各項目とも「できない」(1 点)，「あまりできない」 (2 点), 「どちらでもない」(3 点), 「ある程度できる」 (4 点), 「十分にできる」(5 点), の 5 つの選択肢を設 定した。なお，(1) (4)が全身の移動，(5)〜(8)までが上 肢の操作，(9)〜(12)までが手指の操作，(13)（16)が起立・ 姿勢変換の下位尺度を表している。
付録 2 活動能力の質問紙（古谷野ら，1987）

(1) バスや電車を使って一人で外出できますか

（2）日用品の買い物ができなすか

（3）自分で食事の用意ができますか

（4）請求書の支払いができますか

（5）銀行預金・郵便貯金の出し入れが自分ででき亡 すか

（6）年金などの亩類が畫けますか

（7）新聞を読んでいますか

(8) 本や雑誌を読んでいますか

(9) 健康についての記事や番組に興味がありますか

(10) 友だちの家を訪ねることがありますか

(11) 家族や友だちの相談にのることがありますか

(12) 病人を見舞うことができますか

(13) 若い人に自分から話しかけることがありますか 各質問とも「はい」(1 点)，「いいえ」(0 点)，の2 つの選択肢を設定した．なお，(1)〜(5)までが手段的自 立，(6) (9) までが知的能動性，(10) (13)が社会的役割の 下位尺度を表している。 